\title{
ІННОВАЦІЙНА ПІДГОТОВКА МАЙБУТНІХ БАКАЛАВРІВ ДОШКІЛЬНОЇ ОСВІТИ: ЗАРУБІЖНИЙ ДОСВІД
}

У статті розглянуто необхідність інноваціийної підготовки фахівців, індикаторами якої є наступні елементи: попередні успіхи студентів у роки навчання в педагогічних навчальних закладах, інформованість про інновації і готовність до їх практичного втілення. Висвітлено зарубіжний досвід інноваційної підготовки майбутніх бакалаврів дощкільної освіти в системі вищих навчальних закладів Європи й Америки, структуру та особливості навчання івикладання в них. Проаналізовано зміст та методику підготовки до використання інноваційних технологій на практиці. Висвітлено новаторські методи роботи (коопероване навчання, методи критичної педагогіки, педагогічної антропологї, аутентичної та етнічної бесіди, тощо), форми організації (кооперативне навчання, мікронавчання, моделювання, мінікурси, виїзні семінари, тощо) та інноваційні моделі навчання студентів-бакалаврів з пошуковою спрялованістю, способи $і$ засоби їх введення у навчальний процес. Виділено необхідні компоненти для створення ефективних ситуацій кооперованого навчання: позитивна взаємозалежність, взаємодія підтримки «пліч-о-пліч», індивідуальна відповідальність, вміння спільно праццювати в малій групі, групова обробка результатів. Розглянуто практичні уління та навички викладача закладу вищої освіти (володіння пояснювальними та дослідницькими методами навчання), які необхідні для ознайомлення студентів із нововведеннями, формування у них стійкої зацікавленості до вивчення та використання в своїй професійній діяльності інновацій, також указано функції викладача у ході навчального процесу (координатор, партнер). Описано методи надпредметної пошукової навчальної діяльності, до якої входять дослідницька, комунікативно-діалогова, дискусійна, ігрова, моделююча діяльність. Висвітлено завдання які стоять перед викладачем закладу вищьої освіти в процесі викладання дисц̨ипліни.

Ключові слова: інноваційна підготовка, майбутні бакалаври, зарубіжний досвід, модель підготовки, інноваційні методи і форми.

Постановка проблеми. Сучасний світ характеризується стрімким розвитком та новаціями майже в усіх галузях нашого життя. Не оминули зміни і освітній процес: впровадження інноваційних технодогій, вкдючення дітей 3 особдивими освітніми потребами у звичайні навчальні заклади, зміна денної форми навчання на дистанційну в зв'язку з пандемією коронавірусу, що зумовидо масовий перехід до навчання в онлайн режимі.

У зв'язку з інтелектуалізацією виробництва, у ряді країн світу ставдяться завдання переходу до обов'язкової вищої освіти (Японія), в інших якість вищої освіти підвищується за рахунок збільшення капіталовкдадень (США, Німеччина, Великобританія) або впровадження високих освітніх технологій (Італія, Франція, Швеція). Підвищення освітнього потенціалу в цих країнах і в Україні зокрема, здійснюється шляхом збільшення витрат на освіту, поліпшення матеріальної бази, комп'ютеризації. Водночас, відзначається нестача нових ідей, досконалих, відповідних потребам часу, технологій навчання та виховання.3 огляду на це підготовку фахівців дошкільної освіти має бути переглянуто відповідно до сучасних тенденцій та нових умов життя. Важливе значення має вивчення та впровадження зарубіжного досвіду такої підготовки.

*C) Машкіна Л. А.

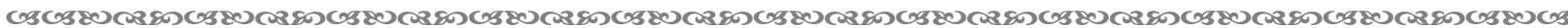
167 
Аналіз досліджень. У сучасних дослідженнях простежується ідея про необхідність інноваційної підготовки в педагогічних навчальних закладах, де б майбутні фахівці отримали не лише спеціальну підготовку, а й практичні вміння. Дослідники Хафер та Стенглад вважають, що існуе позитивна кореляція між освітою та нововведеннями, тобто, чим вищий рівень освіти, тим вищий нахид до новаторства. Відповідно існує також позитивна кореляція між інформованістю та новаторством педагогів. Майда Уршич встановила, що педагоги 3 хорошою інформованістю позитивно ставляться до нововведень i, навпаки, у педагогів 3 поганою інформованістю про інновації існує негативне ставлення до новаторства [1].

Актуальні дослідження вчених (К. Ангеловскі, М. Кларін, М. Поташник та ін.) свідчать про необхідність інноваційної підготовки фахівців. Зокрема, вчений К. Ангеловскі, вивчаючи проблему підготовленості педагогів до сприйняття та застосування нововведень, дійшов висновку, що індикаторами такої підготовленості є такі елементи: попередні успіхи студентів у роки навчання в педагогічних навчадьних закладах, інформованість про інновації і готовність до їх практичного втілення [7].

Науковці вважають, що підготовка до інноваційної діяльності - невід'ємний фактор успіху і головна умова для новаторства та творчого ставлення до справи.

Мета статті - розкрити основні аспекти зарубіжного досвіду інноваційної підготовки майбутніх бакалаврів у закладах вищої освіти, висвітлити його особливості та методику використання.

Виклад основного матеріалу. Особливістю сучасного навчання за кордоном є підготовка студентів до активного освоєння ситуації соціальних змін. Ці освітні орієнтири визнані міжнародною спільнотою як провідні в програмах ЮНЕСКО, де діє спеціальний центр педагогічних інновацій для розвитку освіти.

Сучасна вітчизняна зарубіжна дидактика сьогодні найбільше орієнтується на інноваційне навчання, хоча у практиці навчальних закладів переважає підтримуючий тип навчання.

В останньому десятиріччі в розвинутих країнах світу змінюеться характер навчання у вишах у контексті глобальних освітніх тенденцій, які отримали назву «мегатенденцій». Відомий дослідник проблем із зарубіжної педагогіки М. Кларін до їх числа відносить: безперервність освіти як нову якість та ії масовий характер; значущість освіти як для індивіда, так і суспідьства; спрямованість на активне засвоєння дюдиною способів пізнавальної діяльності; орієнтацію освітнього процесу на запити та потреби особистості; особистісно-зорієнтоване навчання студента, створення умов для його саморозкриття [7].

Про необхідність змін у вітчизняній підготовці фахівців свідчить аналіз сучасних зарубіжних систем підготовки кадрів, які відзначаються гнучкістю, відповідністю характеру різних систем дошкільної освіти. Так, у Японії, де, незважаючи на високу платню, у дошкільних закладах виховується більше половини дітей цього віку, досить висока якість виховної роботи забезпечується тим, що педагогів готують на найвищому рівні - у педагогічних університетах і коледжах.

У Франції, яка посідає одне з перших місць у світі за забезпеченістю дошкільними закладами, педагоги навчаються у чотирирічних закладах - «нормальних школах», які нещодавно отримали статус вишів професійного профілю. Французького педагогадошкільника готують у двох вишах: в університеті та у «нормальних школах», яких налічуеться близько 120. Навчальний план включає чотири блоки: загальнопедагогічний; блок предметної підготовки й ознайомдення 3 новою технікою і технологією; підготовку до виховної та адміністративної роботи; елективні курси (за вибором) [2].

У США фахівці з дошкільної освіти отримують загальну дворічну академічну підготовку, а на їі базі - дво-чотирирічного коледжу, в якому значна увага приділяеться вивченню психічного, фізичного розвитку дитини, нових технологій виховання

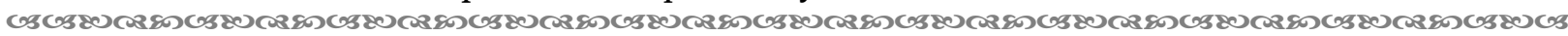
168 
та навчання. Методи підготовки американських педагогів формуються на новій філософії конструктивізму i постмодернізму, яка $\epsilon$, за широким визнанням американських фахівців, філософією людства у XXI столітті. Основні ідеї цієї філософії зводяться до необхідності підготовки відповідальних, творчих, активних людей, які шанують диверситивність, діалог кудьтур і спільне навчання викладачів й студентів. В основі методів, що базуються на цій філософії (коопероване навчання, методи критичної педагогіки, педагогічної антропології, аутентичної та етнічної бесіди, презентації проєктів тощо), лежить організація кооперованого, співробітницького навчання майбутніх педагогів за допомогою диверситивних засобів групової роботи. Вона грунтується на взаємодопомозі студентів, кожний із яких зберігає власну ідентичність, при цьому поважаючи точку зору інших [3].

Американський вчений Д. Джонсон визначає п'ять необхідних компонентів ефективних ситуацій кооперованого навчання: позитивна взаємозалежність, взаємодія підтримки «пліч-о-пліч», індивідуальна відповідальність, вміння спільно працювати в малій групі, групова обробка результатів (Д. Джонсон, Дж. Фдейвель, К. Сміт та ін.) Заслуговуе на особливу увагу концепція метакогнітивності. За визначенням Дж. Флейнеля, метакогнітивність - це рівень особистості щодо власних когнітивних процесів, а також усього того, що їх стосується.

Виділяються різні форми кооперованих груп: формальні кооперовані групи, групи студентського бригадного подіяу досягнень, джигсо і неформальні кооперовані групи. Для роботи в таких групах у студентів необхідно сформувати кооперовані навички, до яких Джонсон зі своїми колегами відносить формувальні, функціональні і формулятивні.

У цілому, коопероване навчання сприяе академічним досягненням, кращому сприйняттю студентами диверситивних оточень, поліпшенню ставлення до дошкільного закладу, також, формуванню більш позитивних «Я-концепцій» студентів [5].

У вищій школі США здійснюеться диференційований підхід до навчання, поширена практика консультування студентів і вибору академічного наставника, який викладає ту дисципліну, що студент обрав як основну. Велика увага приділяється самостійній пізнавальній діяльності студентів (розробка індивідуальних і групових проєктів, проведення теоретичних досліджень, індивідуальне вивчення курсу).

Важливе місце серед форм та методів навчання у вищій школі США виділено мікронавчанню, моделюванню, мінікурсам, веденню карти спостережень за роботою вчителя, вихователя. Заслуговуе на увагу мікронавчання (відпрацювання окремих прийомів роботи вихователя 3 невеликою групкою, також ведеться відеозапис, щоб студенти мали можливість аналізувати свої дії і коректувати їх). Мінікурси - це показ коротких фільмів про роботу досвідчених педагогів та ії аналіз [3].

У США, Англії також поширені практичні заняття в малих групах, мета яких закріпити і поглибити інформацію, а також цілеспрямований уплив на формування особистості, розвиток критичного мислення, самостійності.

У. Макхічі виділяе завдання, які повинен вирішити викладач в ході дискусії: 1) постановка проблеми; 2) забезпечення значимої мотивації участі всіх студентів у дискусії; 3) спрямованість обговорення до необхідної мети; 4) посередництво в роз'ясненні різних думок; 5) узагальнення й оцінка висловлювань; 6) уточнення формулювань, що дають студенти; 7) оцінка роботи групи.

У практиці зарубіжної школи існує тенденція до введення міждисциплінарних навчальних курсів і семінарів, основним видом яких є виїзні семінари. Велика увага також приділяеться самостійній роботі. В цьому плані заслуговує на увагу методика роботи за так званим планом Келлера, в основі якого тривала традиція експериментів на індивідуалізацію навчання, зокрема досліди Ф. Барка, дослідження Скіннера. Працюючи за Планом Келлера, викладач розподіляе навчальний матеріал на розділи os 169 
або навчальні одиниці, до яких студент отримуе друковане керівництво і переходить від вивчення одного розділу до наступного. Таким чином, матеріал з інноваційних проблем вивчається студентом в індивідуальному, зручному темпі, що збільшує потенційні можливості для ефективного засвоєння знань.

Зарубіжні вчені також проводять дослідження, спрямовані на вивчення кола професійних знань, умінь і навичок, необхідних майбутньому педагогу та методи їх формування у процесі навчання у виші (О. Березовські, Б. Бромберек, Ю. Коздовська, Т. Маліновські - Польща: Г. Атанасов. П. Драганов, С. Жекова - Болгарія; Є. Сечі, I. Фалуш - Угорщина; В. Кірш, А. Хумел, У. Шварцер - Німеччина), а також проблеми творчого мислення та творчої інноваційної діяльності (В. Калвейт, Г. Нойнер Німеччина).

Як свідчать публікації, шляхи ознайомлення студентів 3 новими технодогіями в зарубіжній вищій школі здійснюються на основі моделі навчання як творчого пошуку нових знань, так і пізнавальних орієнтирів високого рівня складності (Е.де Боно, Д. Брунер, Е. де Корте, Д. Мезероу, М. Ноуелз, Х. Таба, Д. Шваб ін.). Процес навчального інноваційного дослідження стає визначальним («процесуально-орієнтоване» навчання) і спрямованим на освоєння студентами процедур пошукової діяльності. Основними варіантами моделі творчого пошуку є: систематичне дослідження, спільне вироблення позицій, прийняття рішень на основі дискусії, гри, моделювання в предметнозмістовому та соціально-психологічному плані.

Науковці, зокрема, М. Кларін визначають, що в основі нових моделей навчання 3 пошуковою спрямованістю $є$ надпредметна пошукова навчальна діяльність, до різновидів якої належить дослідницька, комунікативно-діалогова, дискусійна, ігрова, моделююча діяльність. Надпредметна пошукова діяльність щодо організації студентами власного пізнання в інноваційних пошуках займає основну роль. Сучасні психологопедагогічні дослідження намічають орієнтири для роботи за традиційними проєктами і переходу до формування інноваційних ідей у ході навчального процесу. Ці орієнтири можна представити як комплекс психолого-дидактичних вимог.

- Виникнення у студентів почуття незадоводення змістом та методикою навчання дітей.

- Студенти повинні чітко усвідомити зміст нових ідей.

- Спроможність пов'язати нове поняття з уже існуючим. ідей [6].

- Нові технології повинні вирішити не вирішену проблему, вести до нових

Як свідчать досдідження, студентам дають мождивість дослідити нові ідеї, технології спочатку шляхом обговорення в нових групах і застосування на практиці так, щоб вони могли оцінити їх прикладне значення. Дослідницька спрямованість навчання дає мождивість студентам в ідеалі зацікавитись новими технологіями та апробувати їх на практиці.

Багато зарубіжних дидактів (Д. Шваб та ін.) ратують за три рівні дослідницького навчання: висунення викладачем інноваційної ідеї і пропозиція методу ії впровадження. Вирішення і пошук необхідно здійснити студентам; постановка викладачем інноваційної проблеми, метод втілення якої студенти шукають самостійно; самостійна постановка студентами інноваційної проблеми, пошук методу та розробка рішення.

Здійснюючи підготовку фахівців до реалізації проблемного навчання, викладач вишу повинен володіти як пояснювальними, так і дослідницькими методами навчання. Він повинен виконувати функцію координатора i партнера, повинен зацікавити студентів проблемою (новою технологією) і процесом іï гдибокого дослідження. Йому слід дати лише основні уявлення і поняття, закладені в зміст нової ідеї, а решту студенти пізнають самостійно. Для цього їм надається можливість самостійно планувати своє дослідження, визначати його аспекти, апробувати на практиці. Вони можуть піддати 
сумніву прийняті уявлення, ідеї, включають у пошук альтернативні інтерпретації, які вони самостійно формулюють, обгрунтовують [4].

У дослідженні Д. Колба, Д. Дьюі, представлена узагальнена модель навчання, що грунтується на власному досвіді студентів. Це конкретний досвід (висока сприйнятливість нового досвіду); рефлексивне спостереження (рефлексія досвіду, його інтерпретація); абстрактна концептуалізація (цілісне розуміння вироблення понять, уявлень, створення послідовної логічної теорії); активне експериментування (використання теоретичних знань для вирішення проблеми, набуття нового досвіду) [5].

Висновки. Таким чином, аналізуючи тенденції розвитку освіти в світі та в Україні, підсумовуючи досвід зарубіжних і вітчизняних науковців, можемо зробити висновок, що сучасний стан підготовки майбутніх бакалаврів до використання інноваційних технологій у своїй діядьності потребуе корекції, що зумовлює необхідність перегдяду та оновлення існуючих програм і методик навчання, які могли б задоводьнити потреби сучасності.

Вищевказані дослідження наводять на думку, що шляхи ознайомлення студентів із нововведеннями невід'ємно пов'язані з пошуковими моделями навчання, якими повинен володіти викладач закладу вищої освіти, також використовувати в своїй діяльності систематичне дослідження, рольові навчальні ігри, різні форми дискусіі та прийоми зацікавлення студентів глибоким вивченням інновацій в освіті.

Перспективи подальших розвідок у даному напрямі ми вбачаємо у розробці сучасних моделей зарубіжного досвіду щодо інноваційної підготовки майбутніх бакалаврів, змісту педагогічної практики з цього питання тощо.

\section{Список використаних джерел:}

1. Гавриш Н. В. Підготовка майбутніх фахівців дошкільного профілю до інноваційної діяльності як педагогічна проблема. Гуманітарний вісник ДВНЗ «Переяслав-Хмельницький педагогічний університет імені Григорія Сковороди»: науково теоретичний збірник. ПереяславХмельницький, 2008. Вип. 14. С. 50-53.

2. Козак Л. Підготовка майбутніх фахівців дошкільної освіти: європейський досвід. Неперервна професійна освіта: теорія і практика. 2017. Вип. 3-4. С. 136-142.

3. Корінна Г. Підготовка майбутніх фахівців дошкільної освіти до професійної діяльності в умовах європейського освітнього простору. Проблеми підготовки сучасного вчителя. 2017. Вип. 16. С. 284-291.

4. Кузьмінський А. І. Педагогіка вищої школи: навчальний посібник. 2-ге видання. Київ: Знання, 2011. 486 с.

5. Куліш Р. В. Підготовка майбутніх фахівців дошкільної освіти до професійної діядьності. Науковий вісник Миколаӥвського державного університету імені В. О. Сухомлинського. Сер.: Педагогічні науки. 2014. Вип. 1.45. С. 73-77.

6. Машкіна Л. А. Зарубіжний досвід підготовки студентів до інноваційної діядьності. Підготовка майбутніх фахівців до освітньої діяльності в дошкільному навчальному закладі: [кол.моногр.]. Хмельницький: ХГПА, 2015. С. 64-74.

7. Поніманська Т. І. Дошкільна педагогіка: підручник. К.: Академвидав, 2015. 456 с.

\section{References:}

1. Havrysh, N. V. (2008). Pidhotovka maibutnikh fakhivtsiv doshkilnoho profiliu do innovatsiinoi diialnosti yak pedahohichna problema [Training of the future specialists of pre-school profile to innovation activities as a pedagogical problem]. Humanitarnyi visnyk DVNZ «PereiaslavKhmelnytskyi pedahohichnyi universytet imeni Hryhoriia Skovorody», 14, 50-53 [in Ukrainian].

2. Kozak, L. (2017). Pidhotovka maibutnikh fakhivtsiv doshkilnoi osvity: yevropeiskyi dosvid [Preparation of the future specialists of pre-school education: European experience]. Nepererona profesiina osvita: teoriia i praktyka, 3-4, 136-142 [in Ukrainian].

3. Korinna, H. (2017). Pidhotovka maibutnikh fakhivtsiv doshkilnoi osvity do profesiinoi diialnosti $\mathrm{v}$ umovakh yevropeiskoho osvitnoho prostoru [Preparation of the future specialists of pre-school 
education to professional activity under the conditions of European educational space]. Problemy pidhotovky suchasnoho vchytelia, 16, 284-291 [in Ukrainian].

4. Kuzminskyi, A. I. (2011). Pedahohika vyshchoi shkoly [Pedagogy of high school]. Kyiv: Znannia [in Ukrainian].

5. Kulish, R. V. (2014). Pidhotovka maibutnikh fakhivtsiv doshkilnoi osvity do profesiinoi diialnosti [Preparation of the future specialists of pre-school education to professional activity]. Naukovyi visnyk Mykolaivskoho derzhavnoho universytetu imeni V. O. Sukhomlynskoho. Pedahohichni nauky, 1.45, 73-77 [in Ukrainian].

6. Mashkina, L. A. (2015). Zarubizhnyi dosvid pidhotovky studentiv do innovatsiinoi diialnosti [Foreign experience of training students to innovation activity]. In Pidhotovka maibutnikh fakhivtsiv do osvitnoi diialnosti $v$ doshkilnomu navchalnomu zakladi [Preparation of the future specialists to educational activity in pre-school educational institution] (pp. 64-74). Khmelnytskyi: KhHPA [in Ukrainian].

7. Ponimanska, T. I. (2015). Doshkilna pedahohika [Pre-school Pedagogy]. Kyiv: Akademvydav [in Ukrainian].

Mashkina L. A., orcid.org/0000-0002-4942-7924

\section{INNOVATIVE PREPARATION OF FUTURE CHARACTERS OF PRESCHOOL EDUCATION: FOREIGN EXPERIENCE}

The article describes the importance of studying the successful teaching experience in pedagogical educational institutions of the world, considers the foreign experience of innovative teaching of future bachelors of preschool education: the system of higher education institutions in Europeand America, the structure and features of teaching and learning in them. The content and methods of preparation for the use of innovative technologies in practice are analyzed. Innovative methods and forms (cooperative learning, methods of critical pedagogy, pedagogical anthropology, microlearning, modeling, minicourses, etc.) are covered. Innovative models of teaching bachelor students with search orientation, as well as ways to implement them in the educational process are outlined.The necessary components for creating effective situations of cooperative learning are identified: positive interdependence, interaction of support "sidebyside", individual responsibility, ability to work together in a smal l group, group processing of results. The practical skills and abilities of a teacher of a higher educational institution, necessary for acquaintance of students with innovations, methods of forming their stable interest in studying and using innovations in their professional activity, are considered (systematic research, role-playing games, various forms of deep study of innovations in education). The functions of the teacher during the educational process (coordinator, partner) are indicated. Methods of suprasubject search educational activity are described, which include research, communicative-dialogue, discussion, game, modeling activity, description of the tasks facing the teacher of higher education in the course of teaching the discipline.

Key words: innovative education, future bachelors, foreign experience, learning model, innovative methods and forms. 